\title{
Moderneja yhteisöjä ja yksinäisyyttä
}

Uuden vuosikymmenen ensimmäisen Avaimen artikkelien aiheet nivoutuvat yhteisön ja yhteisöllisyyden sekä toisaalta yksinäisyyden teemoihin modernisoituvan kansakunnan ja kyläyhteisön sekä modernin kaupunkiympäristön konteksteissa. Avain on itse avoin yhteisö ja toivottaa tervetulleiksi erilaisia kirjoituksia kirjallisuudesta. Tässä numerossa on kolme artikkelia ja viisi kirja-arviota.

Numeron avaa Antti Ahmalan artikkeli "Januskasvoinen nykyaika: Moderniteetti ja traditio Volter Kilven Kansallista itsetutkistelua -pamfleteissa". Ahmala tarkastelee Suomen itsenäisyyden alkuvuosien ja sisällissodan tienoilla kirjoitettujen pamflettien nykyaikaistumisen tematiikkaa ja lukee Kilven tekstiä antimoderniuden käsitteen valossa. Ahmala liittää Suomen tilannetta käsittelevät Kilven tekstit laajempaan 1900-luvun alun kansainväliseen, konservatiiviseen ilmapiiriin, mutta osoittaa myös, että antimodernin nostalgian rinnalla pamfleteissa kulkevat edistysmieliset ideat.

Lehden toisessa artikkelissa Noora Vaakanainen tarkastelee yhteisöllisyyden poetiikkaa Kristina Carlsonin romaanissa Herra Darwinin puutarhassa. Carlsonin teoksen keskiössä ovat kollektiivisen maailmankatsomuksen ja modernisoituvan maailman väliset jännitteet. Vaakanainen keskittyy analyysissään kollektiiviseen kerrontaan, juoruun sekä lintu-tematiikkaan ja korostaa, ettei romaanin yhteisöllisyyden poetiikkaa voi typistää mihinkään tiettyyn kielelliseen tai kerronnalliseen keinoon.

Kolmas artikkeli on Riikka Ylitalon "'Pelkään kaupunkia': Naisen tunteita Tua Forsströmin ja Arja Tiaisen 1970-luvun lyriikassa". Ylitalo lukee Forsströmin ja Tiaisen runojen naisten kaupunkikokemuksia tunne- ja tilatutkimuksen viitekehyksessä. Keskeisiä 1970-luvun suomalaista kaupunkiympäristöä naisten näkökulmasta määritteleviä tunnetiloja ovat pelko, yksinäisyys ja ulkopuolisuus. Toisaalta Tiaisen ja Forsströmin lyriikassa myös haastetaan teosten julkaisukontekstissa yleistyneitä negatiivisia käsityksiä lähiöistä toivottomina paikkoina, joissa ei ole yhteisöllisyyttä.

Tämän numeron kirja-arviot liittyvät elämäkertoihin tai niiden tutkimukseen. Heta Marttisen arvioitavana on Maarit Leskelä-Kärjen Toisten elämät: Kirjoituksia elämäkerroista. Minna Maijala ja Marianne Roivas arvioivat kumpikin tahollaan Panu Rajalan laatimia elämäkertoja Eino Leinosta ja Ilmari Kiannosta. Muut arviot ovat Maria Saleniuksen arvio Liisa Steinbyn ja Aino Mäkikallin toimittamasta teoksesta Narrative Concepts in the Study of Eighteenth-century Literature, sekä Jussi Ojajärven arvio tuoreesta artikkelikokoelmasta Muistikirja ja matkalaukku: Muotoja ja merkityksiä 2000-luvun suomalaisessa romaanissa, jonka ovat toimittaneet Elina Arminen ja Markku Lehtimäki. 